\title{
HER THIRTY-SEVENTH YEAR, AN INDEX
}

\section{$A$}

Anecdote, You tell him that you are writing a story about him. You ask if he's heard the one about Flannery O'Connor and the young and handsome textbook salesman. He courted her, took her for a drive, kissed her. She didn't know how to kiss, as it happened. I had a feeling of kissing a skeleton, he described the experience in a letter to a friend. Some weeks later, upon hearing that he'd married, she sat down to write "Good Country People"; she sent the finished story to him, with a note: This is not about you.

$B$

Belief, In the height of summer, just past the solstice, she fell into what her doctors characterized as a chthonic depression. The young shrink on the case noted that she'd been off medication too long. She lost weight; she wasn't sleeping-sort of classic and boring was how she described it to a friend. She explained something of her desires to the young shrink, who responded, "I don't think you really feel that way. I think that's the voice of depression talking." A part of her wants to believe the young doctor-to believe that her beliefs-her overvalued beliefs - are borne of a chemical disorder. A chemical imbalance. Something separate from what feels like herself. That would comfort, in its way.

Blind spot, The thing about one is that you can't see it. You will feel like you are flying but then wonder if you are falling. You are falling. You are falling.

Boredom (see also: Inner Resources, see also: Marriage), which Tolstoy defined as the desire for desires.

C

Cabbages (see also: Happiness, see also: Woolf, Virginia), Sally asked (she herself was extremely happy); for, she admitted, she knew nothing about them, only jumped to conclusions, as one does, for what can one know even of the people one lives with every day? She asked, Are we not all prisoners? She had read a wonderful play about a man who scratched on the wall of his cell, and she had felt that was true of life-one 
scratched on the wall. Despairing of human relationships (people were so difficult), she often went into her garden and got from her flowers a peace that men and women never gave her. But no; he did not like cabbages; he preferred human beings, Peter said.

Cake, which you eat as you sit in the café, waiting for him. Frances McDormand will be sipping tea at the next table and you will find it difficult not to stare. She will stare back, in a nice way. She isn't wearing makeup. She will be beautiful in real life, more beautiful than she appears on film, and this will remind you of something.

Closure, as when you tell him that it was his fault, that he took advantage, that you were vulnerable. Also: what you hoped his arrival might offer, what we all hoped, with the knowledge that one lover will call up a past love or experience, the knowledge that fantasy will intermingle with reality.

Confession (see also: Language), He wants to talk: There are so many things about myself that I want to tell you. You want to stay on the phone with him for hours. You will fall in love with his voice, which is not the body, but links to it.

Consequences, It may cause you to suffer, the wetness of your panties; your desire to be touched by a married man.

Containment (see also: Memory, see also: Theater), Dearest $X, I$ was watching a woman on stage last night, a young woman, and I had a memory of a woman from the ward for promising young women. Meredith. She was something of an aberration on the ward. Everything about her was contained. She was perpetually tan and maintained, somehow, a crisp, short blonde haircut. She wore tennis skirts and tight little sundresses that revealed her thick tan legs, which were punctuated by white Keds. She smoked thin Virginia Slims. She was from Greenwich; she would be sure to tell you. She would talk with the Aides and laugh, but when she laughed her mouth only opened so far and the rest of her face didn't move. There was such a sadness about her-the containment-so it didn't bother me or anyone too much the way she talked about the others: Ava with her scars, Maria with her fingers down her throat, Jennifer with her various personalities. Jennifer who, we all knew, would never leave. Jennifer who had become a part of the place. Jennifer whose father raped her lying face down in his work shed. Jennifer who still ate nails, liked the taste of nails, couldn't help herself. 
Courtship, He will ask for more. I want to read you, he will write.

Cupcake, You eat chocolate cupcakes with chocolate frosting and beautiful flowers. Your body will feel like it's on fire. You will call Dread. He will refer you to his expensive healer. You will call the expensive healer. She will call you sweetie, and she will tell you that it's going to be okay.

D

Death (see also: Friendship), Dearest $X$, Last night I went out for expensive Korean food with a girlfriend. I drank one glass of wine and felt a little drunk. She is so intense, my friend. Later I had that Kierkegaardian feeling that I give her too much, that she takes something of me, from me, that it's vampiric, our friendship. She tells me her mother was this way, and I don't know what it would be like to have a mother so invested in me, my well-being, I don't know and so I take this from my friend, this is why I love her, why I was first drawn to her, she cares about me-and she tells me this. I care about you, she says. I believe her. Is that foolish? Later we drive home and decide that we're each having a midlife crisis, in our own personal special stupid ways. Her childhood friend has cancer, she explains: "And I feel like saying to her, Now really did you have to get cancer? Do you have to remind me that we're all going to die, that I'm also going to die, which is something I cannot accept right now? At all. Really did you have to?" She starts to cry. I get it, I say. It's why I'm obsessed with desire, I say, which is the opposite of death, as Tennessee Williams wrote, but also dangerous, in the way death is dangerous. As my desire for death is dangerous. We laugh then. I care about you, too, I say. I never say things like this to friends, but she brings it out in me. She makes me a better friend. Which is why I will say it here to you, too, my dearest: I care about you.

Dreams, of airplanes, tall buildings, healing; you wake at two a.m. to see the Manhattan skyline over the promenade. You know yourself again, or think you do. I am home. I am home, you say to the sky, the water, the possibility of all things.

Desire (see also: Boredom), A friend describes it this way: My crushes are usually like-I want him to fuck me against the wall. Another friend explains, For me, marriage-monogamy, rather-means that I will never reach my sexual potential. 
E-mail, You will read his one line: looking forward to hearing your voice, and it will make you wet. He eschews capitalization, which somehow makes the note sexier. If it were from a student, you would not find the use of lowercase sexy; you would find it disrespectful, an indication of stupidity. You sit at your desk wet, wondering at the link between language and desire. You walk into class. You teach the poems of Edna St. Vincent Millay with your panties wet. You wonder if this is the only real thing in the world anymore, the only true thing: the wetness of your panties.

Exceptions, He loves you but feels three things: bored; lonely; invisible. Also: he thought this sort of longing, desperation, was for sad old people.

F

Fantasy, A dog will present as a lobster, a child as a serpent.

Friendship (see also: Love, see also: Desire), for example, you meet a man to whom you reveal a secret that may or may not be true. You discover that there isn't language for this sort of friendship.

G

Good people (see also: Tragedy), From a letter in H.'s safe box, Nov. 2009: My dearest $X$, You are a good person and because you are a good person I am going to like you even more than I already do. But still there might exist a part of me that wishes you were not such a good person, that instead you would say let's meet somewhere for a day or a night. And if you said that, I would say Yes. And we would meet and have really hot sex, and it would be great. Afterward, we would return to our conventional lives where we attempt to be good people. But instead, of course, you say, Let's be friends! and I say, Yes let's! And we become friends in the manner of Oscar Wilde, where friendship is more tragic than love, if only because it lasts longer.

H

Hardwick, Elizabeth (see also: Betrayal, see also: Hunger), Seduction may be baneful, even tragic, but the seducer at his work is essentially comic. The seducer as a type, or as an archetype, hardly touches upon any of our deep feelings unless there is some exaggeration in him, something complicated and tangled and mysteriously compelling about a nature that has come to define itself through the mere fact of sex. For 
the most part, the word "seduction" indicates effort of a persevering, thoughtful sort. A seduction is the very opposite of the abrupt, which is, of course, rape. The most interesting seducers are actually rapists: for instance, Don Giovanni and Lovelace. Their whole character is trapped in the moil of domination, and they drudge on, never satisfied, never resting, mythically hungry.

Holiday, I took a hot bath. I spoke to you. I drank two glasses of wine. I kissed my baby. I left the room. I had trouble communicating. I read three poems by three men. I read "The Pornographic Imagination." I sleep. I dream of you.

$L$

Lessons, You will teach "One Art." You will tell your students that writing is like losing. That writing is losing. You correct yourself. They look confused. You try to explain. When you read the poem, as when you read Auden, you cry. A student sits with his ass hanging out of his pants. You want to pull up his pants.

Lispector, Clarice (see also: Love, see also: Solitude), At this time of day she often wishes to be alone and dead to everything in the world, except for the one man whom she does not yet know and whom she will create for herself.

Loneliness, You remember reading an interview with Anne Carson, who said that loneliness is not a significant problem. The doctor will ask you, How bad does it get, the loneliness? And you feel uncomfortable measuring such a thing; you feel she's failed to understand your experience. She meant to be comforting, but the question only makes you lonelier.

$M$

Marriage, Your husband will call. I miss you, you will say. I love you, you will say. I want to move back to New York, you will say. He will either not hear you or he will ignore you. I have to get some work done, he will say. We can talk tomorrow, he will say. Goodnight. Love you. Goodnight.

Memory, A teacher reading a poem about a married woman who wanted the gas attendant to put a hand on her breast; who wanted to grab a pretty woman, a friend burning with desire, complaining about the normative brotherly lust of marriage. And the way you giggled, you and your silly Catholic 
schoolgirl classmates, embarrassed for the teacher, wishing away her gooey lust.

Mothers (see also: Bliss, see also: Desire), Dearest X, Yesterday I visited a friend with a new baby, a friend who told me that she does not feel as happy as she should feel. That she expected to feel sheer bliss at the arrival of her second child, but instead it has been something else; a letdown. She does not have a personality like mine, she does not tend toward the darkness, and so it surprised me to hear her speak this way. But I understood her, though I cannot understand. I understand, I told her.

$P$

Passive Intentionality, a friend calls it, warning you.

Pathos (see also: Platonic affair, see also: Religion), Dearest X, I think we are lovely. I think we are searching, blind, groping in the dark, like all chosen people. I went to church yesterday. I haven't been in years. I liked that the priest quoted Keats. I liked that the priest noted that we are all Zacchaeus-but I feared the inherent anti-Semitism. I want things to be different. I want to believe in God. I want to believe in something.

Phaedra (see also: Lacan, see also: Poetry, see also: Racine), In Coeur de Lion, A. Reines writes, "I love when Racine makes / Phaedra say I LOVE instead / Of I LOVE YOU. She was / Not too proud." Simone Weil calls Phaedra's love impure. In her case, Weil writes, the passion of love goes as far as vegetative energy. Sontag writes: The obscene, that is to say, the extremity of erotic experience, is the root of vital energies. Human beings live only through excess.

Philosophy, Your analyst will say, "Your marriage is not working because you are depressed," and you will agree; your friend will say, "You are depressed because your marriage is not working," and you will agree.

$R$

Reality, as when he speaks of the life that is real and the life that is unreal. As when you ask: how can one tell the difference? Or the way you forget that his interest in you is wholly professional, that he wants something, merely. You will forget, and you will feel a connection to him, to his voice on the phone, to the promise of his body across from your own, which is hysterical and problematic, an insoluble problem. Your body. You will stand next to 
him. He will bring you water, Dixie cups full, over and over again. You are so thirsty.

Religion (see also: Memory, see also: Desire), Didi: Do you believe in the life to come? Gogo: Mine was always that.

Rendezvous, He will suggest meeting. It will turn you on. You will wonder about yourself. But not so much as to stop you from replying, and too quickly, Yes.

Romero, Encarnación Bail (see also: Mothers), variously described as an undocumented worker/migrant worker/illegal immigrant; Romero's two-year-old son, Carlos, is taken from her when the plant where she works is raided; she is put in jail. Carlos is taken by the state until he is allowed to be adopted. Encarnación remains in jail. She will never again see her son.

$S$

Sad, You might feel alive again, connected again to something that has been lost, that you lost years ago. You might imagine accessing the infinite through him, through this, which is all you've ever wanted.

Sanity (see also: Sontag, Susan, see also: Weil, Simone, see also: Truth), Susan Sontag writes that of course she comes down on the side of sanity that of course no one would wish for his/her child to live as Simone Weil and yet everyone reads Simone Weil, searching for the truth that they know she possessed. Sontag begins in a flurry, stating that Weil's truth was necessary for this age that it was the hysteric voice that we needed a truth to contrast with the other problematic voices and yet what we also know was that it was not true. In conclusion, she states that she believes in the truth of sanity, but she will not say that the voice of insanity is untrue.

Seduction, He will read your book. Poetry: academic, obscure, abstruse is how the critics describe it. No one reads your book, but he will read it: thoughtfully, carefully. 
Sontag, Susan (see also: Truth, see also: Inspiration), Art must mount a fullscale attack on language itself, by means of language and its surrogates, on behalf of the standard of silence.

\section{$T$}

Theater (see also: Memory, see also: Containment, see also: Madwomen), My dearest $X$, these women will always be with me. I don't know where they are, if they are alive or dead. But they often appear to me, and in the most unexpected moments. I used to walk by Meredith's room and catch her arranging her many tiny glass figurines on the shelves of her room. She would spend hours arranging the tiny glass figurines and, because our rooms didn't have doors, I often stood there watching her. No one was allowed to have glass, but for Meredith an exception was made. She needed the figurines, needed to arrange the figurines, needed to be contained. The allusion to Tennessee Williams was so heavy, so obvious, that no one spoke of it. Maybe Lyle spoke of it, in one of his lectures to medical students. It was the kind of detail he savored.

Time, as when you tell him you have plenty. Which you have not told anyone in years.

Tragedy, as when you tell him that you are happy that the two of you are going to be friends.

Triangulation (see also: Villanelle, see also: Marriage), On day ten, he will tell you that he is writing a villanelle for a woman. And so you will tell him that your husband writes villanelles. Would he like to read your husband's villanelles? You will know that it is inappropriate to mention your husband's talent with the villanelle. But then you will remember: he is not your boyfriend. He is married. You were just trying to be a grown-up, you will say, apologizing. You tell him that you don't know the etiquette. Is there etiquette? you ask. He will say Yes. The first piece of etiquette, he explains, is that you don't mention your husband.

W

Wishes (see also: Desire), And toward the luxurious quotidian: I wish for one or two more students like the one who shook my hand and said It's been a pleasure or the one who said Thank you for the semester as if it were a gift (it was) or the one who asked me to watch his favorite movie and then whispered, And e-mail me after you do. A Single 
Man. A sad movie, from a Christopher Isherwood novel I haven't read. A day in the life of a grieving man. I e-mail the student, but I don't tell him that I understand that grief, how perception alters, shifts, what it is to be undone by grief, the effort that must go into daily life. I tell him that I was moved by the highly stylized, melancholy movie. I tell him I liked especially when the single man (I forget his name) tells a student: the only thing that's made the whole thing worthwhile has been those few times when I've been able to really truly connect with another human being.

Woolf, Virginia (see also: Orgasm, see also: Cabbages), Something now leaves me; something goes from me to meet that figure who is coming, and assures me that I know him before I see who it is. How curiously one is changed by the addition, even at a distance, of a friend. How useful an office one's friends perform when they recall us. Yet how painful to be recalled, to be mitigated, to have one's self adulterated, mixed up, become part of another.

Weil, Simone (see also: Desire), To see each human being (an image of oneself) as a prison in which a prisoner dwells, surrounded by the whole universe.

Writing (see also: Cixous, Hélène), To my sincere surprise, which is only the product of a form of blindness, I realized in time that the writers I love above all are of the dying-clairvoyant kind.

$X$

$X$, or $X$-ing, which might refer to sex, or to love, or to you (see also: $\mathrm{X}$ marks the spot, see also: X-rated, see also: X-ed out). The thing is, I really need you with me in this story. 
Author's Note

"Her Thirty-Seventh Year, An Index" is influenced both directly and indirectly by the following sources: Coeur de Lion (Ariana Reines); The Waves and Mrs. Dalloway (Virginia Woolf); "The Pornographic Imagination" (Susan Sontag); Clarice Lispector; In the Wake (Lisa Kron); Mary Gordon's essay on Flannery O'Connor; and Elizabeth Hardwick's Seduction and Betrayal. 